\title{
2.7 Розвиток професійної компетентності педагогічних працівників закладів дошкільної освіти засобами мультимедійних технологій (на прикладі фінляндії, швеції, норвегії, данії)
}

В умовах інформаційних процесів вагомого значення для української педагогічної науки i практики набуває вивчення зарубіжного досвіду використання мультимедійних технологій в освіті, що $є$ особливо актуальним для розв’язання проблем розвитку професійної компетентності педагогічних працівників закладів дошкільної освіти, що забезпечуватимуть конкурентноспроможнього, активного та компетентного фахівця, здатного до постійного мобільного розвитку власної професійної, зокрема ІКТ компетентності.

Науковий інтерес викликають праці вчених про сучасний досвід підготовки вчителя у Швеції (Н. Кошарна); зміст і напрями професійної підготовки фахівців у Данії (О. Леонтьєва, О. Матвієнко); формування системи вищої освіти у контексті Болонського процесу в Норвегії (В.Семілетко, В. Стинська); реформування, модернізацію освітньої системи у західноєвропейських державах (О. Карпенко, П. Кряжева, Г. Поберезська, А.Ржевська).

За висновками PISA, ефективність освітньої системи Фінляндії потребує усебічного ii вивчення та запозичення як найкращого досвіду [141]. Стратегічним ідеалом фінського суспільства $є$ постійне нагромадження «капіталу знань» - від раннього дитинства й аж до найвищих наукових ступенів і навчання дорослих» [142].

Унікальність фінської системи полягає у широкому використанні мультимедійних засобів та інформаційних мереж у тісному взаємозв'язку 3 педагогічною підготовкою спеціалістів дошкільної освіти. Дані науковців виділяють цифрові навчальні ресурси (Digital Learning Resources), відкрите та дистанційне навчання (Open and Distance Learning), систему управління навчанням (Learning Management Systems); навчальні платформи (Pedanet, Moodle, Optima, Its learning, Claned) [143, c. 4]. 
THEORETICAL FOUNDATIONS OF THE FUNCTIONING OF EDUCATION. WAYS TO

IMPROVE THE EFFECTIVENESS OF EDUCATIONAL ACTIVITIES

Науковець К. Котун, досліджуючи питання розробки компетентнісних моделей Фінляндії, виділяє низку комунікативних технологій, таких як система управління WebCT (інструмент, який надає можливість створювати професійні он-лайн курси та підготовку друкованих матеріалів для покращення таких курсів); платформа Moodle (система управління курсами, тобто електронне навчання, також відома як система управління навчанням або віртуальне навчальне середовище; вільний, але розповсюджений за універсальною загальною ліцензією (GNU General Public License); веб-додатки, що надають можливість створювати сайти для онлайн-навчання; використання двосторонньої аудіо/відео телеконференцій та інші [145]. Зокрема використовуються ІКТ-базовані інтерактивні канали, такі як: електронна пошта, чати, Фейсбук, Вікілайф та інш. Навчання здійснюється через технологію Web 2.0: Вікі (веб-сайт, що дозволяє користувачам змінювати самостійно зміст сторінок через браузер, використовуючи спрощену і зручнішу, порівняно 3 HTML, вікі-розмітку тексту), Netvibes (персональний робочий стіл); різноманітні блоги та інші. На використання нових брендів вказує інтерактивна дошка (Interactive Whiteboard) Clever-board, AKTIV-board, SMART-Board та інші [146, c. 7].

Серед останніх проектів можна виділити: «Багатовимірне навчальне середовище», «Чисте покоління» (Net Generation), «Відповідальність в ІКТ» (Responses to ICT), «Особисте навчальне середовище» (Personal Learning Environments), «Неперервна педагогічна підготовка» (Continuing Teacher Training), «Електронне навчання» (E-Learning), «Педагогіка в ІКТ» (Pedagogy of ICT in General), «Багатовимірне навчальне середовище» (Multidimensional Learning Environments) Найбільш оптимальним $є$ портал «Opeka» (http://oppika.fi/). Даний онлайн-інструмент забезпечує зворотній зв'язок для педагога; аналіз ситуації у вигляді звіту та рекомендації про те, як далі розвивати використання IКТ в освітньому процесі; підтримку щодо складання плану використання IKT; можливість відслідковувати та оцінювати результати подальшого розвитку[148]. 
THEORETICAL FOUNDATIONS OF THE FUNCTIONING OF EDUCATION. WAYS TO

IMPROVE THE EFFECTIVENESS OF EDUCATIONAL ACTIVITIES

За рейтингом країн світу за рівнем розвитку IКТ технологій (індекс розвитку IKT в країнах світу - ICT Development Index) Норвегія входить в першу десятку (VIII - Норвегія (індекс 8,47) [149].

Так, програма «еNorge» (електронна Норвегія) репрезентує стратегію розвитку освіти через впровадження найновітніших інформаційнокомунікаційних технологій, реалізацію синергетичних потенціалів особистості до самоусвідомлення, самовдосконалення й саморозвитку (принцип «постійного навчання»), формування впевненості особистості, яке свідчить про сформованість інформаційного суспільства [150].

Норвезька програма становлення й переходу до інформаційного суспільства «Краще використання інформаційної технології у Норвегії» акцентує, що на тому, що «Дистанційна освіта повинна бути пристосована до необхідності індивідів набувати знання й навички з використання інформаційних технологій» [151].

На необхідність кардинальних змін в освіті, зокрема й дошкільній, указує національний проект Норвегії «Неперервна освіта в секторі дошкільного виховання - огляд попиту i пропозицій» («Etter - og videreutdanning i barnehagesektoren - kartlegging av tilbud og etterspørsel»). Актуалізуються компетентності, що забезпечують життєвий успіх людини у напрямку інформатизації. Зазначено потребу використання в освітньому процесі нових інформаційних та комунікаційних технологій, що дозволяють збільшити швидкість сприйняття, розуміння та глибину засвоєння великих масивів знань. Найпопулярнішими серед них є вітчизняне віртуальне навчальне середовище «ClassFrontier», зарубіжні - BHC «Luvit», «It's Learning», «First Class», «Karb», «WebCT», «BlackBoard» i «Learning Space», «Top Class», «Team Wave», «Response» [152].

Цікавим є підхід до порушеної проблеми в Данї, де до сучасних ініціатив Уряду, у сфері професійної освіти, віднесено підвищення рівня мультимедійної компетентності педагогів дошкільної освіти. Чинна модель неперервної 
THEORETICAL FOUNDATIONS OF THE FUNCTIONING OF EDUCATION. WAYS TO

IMPROVE THE EFFECTIVENESS OF EDUCATIONAL ACTIVITIES

професійної освіти в Данії свідчить про наявність інноваційних підходів в управлінні та організації цісї системи [153].

Проекти "Playful computer writing", "Writing to read" підкреслюють важливість надання дітям дошкільного віку доступу до ІКТ. Особливою новацією є використання ігрових методів навчання 3 комп’ютером для дітей 6 років.

Дошкільна освіта Швеції розглядається як перший самодостатній елемент системи неперервної освіти.

За П. Хенуолом, більшість шведських батьків виступають проти впровадження ІКТ в практику дошкільної освіти, мотивуючи це негативним впливом засобів ІКТ на дітей дошкільного віку. Тому застосування IКТ в практиці багатьох дошкільних закладів Швеції залишається все ще явищем новим. Але швидкий розвиток IКТ, концепція неперервного навчання, забезпеченість дошкільних закладів засобами ІКТ (персональні та планшетні комп'ютери, інтерактивні дошки) спонукають до реформування освітнього процесу відповідно до інтеграції діяльнісного, особистісно орієнтованого та компетентнісного підходів [154].

Шведська національна навчальна програма для дітей дошкільного віку серед пріоритетів називає сприяння розвитку професійної компетентності педагогічних працівників, що забезпечує ефективне використання IКТ в дошкільній освіті [155].

Чинна програма Швеції «IКТ в системі освіти» визначає неперервну педагогічну освіту як трансформуючий чинник, що суттєво впливає на розвиток нової системи освіти в умовах інформаційного суспільства. Увагу приділено заходам, спрямованим на розвиток ІКТ компетентності фахівців дошкільної освіти: проведення курсів підвищення кваліфікації побудованих за принципами мультимедійного навчання і занять з оволодіння цифровою компетентністю; надання після закінчення навчання відповідного сертифікованого документа; адаптування навчальних курсів відповідно до розвитку ІКТ у навчальному середовищі освітнього закладу; розробка мережних (on-line) курсів для реалізації 
THEORETICAL FOUNDATIONS OF THE FUNCTIONING OF EDUCATION. WAYS TO IMPROVE THE EFFECTIVENESS OF EDUCATIONAL ACTIVITIES

концепції навчання протягом життя; покращення координації між науководослідними інституціями у сфері застосування IКТ [156]. На державному рівні моделювання неперервної освіти на основі застосування IКT у педагогічній діяльності та самонавчанні, здійснюється за такими формами як: навчання на виробництві (in-service training) та професійна підготовка на базі університетів (pre-service training). Важливою є однакова статусність усіх видів освіти.

За дослідженнями I. Капустіної, результатом розвитку ІКТкомпетентності шведського педагога $\epsilon$ : мотиваційна компетентність (здатність до подолання психологічного бар’єру при освоєнні IКТ, потреба, прагнення до IКТ знань, ідентифікація власної особистості як «Я - комунікат»); технологічна, «цџифрова» компетентність (уміння користуватися програмами: текстові процесори (word processors), дизайн презентацій (presentation designer), табличні процесори (spreadsheets), бази данних (databases), навчальне програмне забезпечення (computer aided instruction software), засоби розробки сайтів (web page development tools), пошукові системи (search engines), електронний поштовий клієнт (e-mail), списки обговорення і групи новин (discussion lists and newsgroups), чати і форуми (chat and forum), електронні енциклопедіï, атласи (electronic encyclopedia or atlas), браузери (browsers), мультимедійні засоби (instructional films); рефлексивно-педагогічна компетентність (мережна педагогічна взаємодія: міжособистісна, особистісно-технологічна, особистісноінформаційна).

У контексті дослідження розвитку професійної компетентності педагогів засобами мультимедіа, зокрема світового досвіду, $\epsilon$ діяльність центру неперервної освіти (ENCELL (livslangt larande) на базі університету м. Йончопінг. У числі засобів навчального програмного забезпечення використовуються як системи, що розроблені науковцями цього університету (PING PONG, PIM - «Personal Information Manager»; система «Ladok» або «Ladok Novau») так і зарубіжне програмне забезпечення («Levitz», «Mentor», «Telia Instant Education», «Maestro», «FirstClass», «Comenious online», «Lecando», «Librix», «Marratech» i «WebCat»). У системі неперервної освіти поряд із 
THEORETICAL FOUNDATIONS OF THE FUNCTIONING OF EDUCATION. WAYS TO

IMPROVE THE EFFECTIVENESS OF EDUCATIONAL ACTIVITIES

використання CD-ROM та Веб-сайтів 3 готовим змістом передбачено ебібліотеки (Jonkoping University Library), електронні енциклопедіï, атласи (electronic encyclopedia or atlas), мультимедійні засоби (instructional films) [157].

Таким чином, проведення порівняльного досвіду є прикладом успішного використання мультимедійних технологій, що сприяють розвитку професійної компетентності педагогів дошкільної освіти. Перспективи подальших розвідок вбачаємо у моделюванні процесу розвитку професійної компетентності педагогічних працівників дошкільних закладів в системі післядипломної освіти засобами мультимедійних технологій, з урахуванням досвіду зарубіжних країн. 